\title{
Effects of Frozen Storage Temperature and Duration on Changes in Physicochemical Properties of Beef Myofibrillar Protein
}

\author{
Shuyi Qian, ${ }^{1,2}$ Xia Li $\mathbb{D}^{1,2}$ Hang Wang, ${ }^{1}$ Waris Mehmood, ${ }^{1}$ Chunhui Zhang ${ }^{1},{ }^{1}$ \\ and Christophe Blecker ${ }^{2}$ \\ ${ }^{1}$ Key Laboratory of Agro-Products Processing, Ministry of Agriculture and Rural Affairs, Institute of Food Science and Technology, \\ Chinese Academy of Agricultural Sciences, Beijing 100193, China \\ ${ }^{2}$ University of Liège, Gembloux Agro-Bio Tech, Unit of Food Science and Formulation, Passage des Déportés 2, \\ Gembloux B-5030, Belgium
}

Correspondence should be addressed to Xia Li; lixia5299@163.com and Chunhui Zhang; dr_zch@163.com

Received 21 July 2020; Revised 24 December 2020; Accepted 4 January 2021; Published 19 January 2021

Academic Editor: Marcio Carocho

Copyright $(2021$ Shuyi Qian et al. This is an open access article distributed under the Creative Commons Attribution License, which permits unrestricted use, distribution, and reproduction in any medium, provided the original work is properly cited.

This study aimed to address the effects of frozen storage temperature and duration on the changes in physicochemical properties of beef myofibrillar protein. The beef was stored at $-1,-6,-9,-12$, and $-18^{\circ} \mathrm{C}$ for $28,84,126,168$, and 168 days, respectively. The myofibrillar protein of beef samples denatured gradually with the extention of storage period. Regarding the samples stored at temperature range of $-12 \sim-1^{\circ} \mathrm{C}$, higher storage temperature resulted in more severe denaturation (the myofibrillar protein exhibited lower sulfhydryl content, $\mathrm{Ca}^{2+}$-ATPase activity, ionic bonds, hydrogen bonds, and higher surface hydrophobicity). Particularly, difference in -12 and $-18^{\circ} \mathrm{C}$ did not yield significant effects upon the protein properties throughout 168-day storage $(P>0.05)$. These results indicated that lowering freezing temperature may not minimize myofibrillar protein denaturation in a limited storage duration, which was also confirmed by the quality properties of beef.

\section{Introduction}

Beef, containing abundant protein and nutrients, is an excellent food source for human health. Frozen storage has been applied for many years to maintain beef safety and quality. In this regard, freezing temperature is one of the most important factors for extending the shelf-life of highly perishable food such as fresh meat [1]. Superchilling storage $\left(1 \sim 2^{\circ} \mathrm{C}\right.$ below the initial freezing point of products) was also used for beef preservation [2]. This method requires strict temperature control, whereas it is difficult to maintain a stable temperature in the meat-processing industry. Conventional freezing storage $\left(-18^{\circ} \mathrm{C}\right)$ is widely used for long-term beef preservation [3]. However, it consumes a lot of energy during storage and temperature abuse occurs frequently. Hence, it is essential choosing a suitable storage temperature for beef to meet the current demands in the meat-processing industry. Compared to the aforementioned storage temperatures, there is rather limited information on the effects of temperature range of $-3 \sim-18^{\circ} \mathrm{C}$ on meat freezing preservation.

Meat contains approximately $17 \sim 20 \%$ proteins and $65 \sim 75 \%$ water [4]. Consequently, the interaction between proteins and water plays an important role in maintaining the muscle structure. Muscle proteins mainly consist of myofibrillar protein, sarcoplasmic protein, and muscle matrix protein [5]. Myofibrillar protein accounts for $50 \sim 55 \%$ of the muscle proteins, which has a significant effect on the appearance, sensory, tenderness, and water-holding capacity of meat [6-8]. On account of the ice crystal formation and volume expansion, long-term frozen storage could trigger a series of changes to myofibrillar protein [9], such as surface hydrophobicity, $\mathrm{Ca}^{2+}$-ATPase activity, sulfhydryl content, and others [10-12]. However, there is a paucity of understanding on the effects of storage temperature and duration on the changes in physicochemical properties of myofibrillar protein. 
In the present study, the effects of storage temperature and duration on myofibrillar protein denaturation of beef were mainly investigated. Sulfhydryl content, $\mathrm{Ca}^{2+}$-ATPase activity, ionic bonds, hydrogen bonds, and surface hydrophobicity of beef myofibrillar protein were determined during storage at $-1,-6,-9,-12$, and $-18^{\circ} \mathrm{C}$. Moreover, in the end of each storage period, the conformation and physicochemical properties of myofibrillar protein were assessed by using differential scanning calorimetry and Fourier transformation infrared spectrum methods.

\section{Materials and Methods}

2.1. Materials. Bovine longissimus dorsi muscles were obtained from 2-year-old bulls weighing $400 \pm 5 \mathrm{~kg}$ (Simmental $\times$ Mongolian cattle, Mengdu Meat Co. Ltd., Inner Mongolia, China). The initial values of muscle $\mathrm{pH}$ $(5.56 \pm 0.01)$, lightness $(42.1 \pm 1.2)$, redness $(26.5 \pm 0.6)$, and yellowness $(15.1 \pm 0.7)$ of meat samples were determined. After removing the visible connective tissue and external fat, 30 beef longissimus dorsi muscles were cut (perpendicular to the fibre direction) into $50 \mathrm{~mm} * 30 \mathrm{~mm} * 30 \mathrm{~mm}$ pieces $(50 \pm 0.5 \mathrm{~g})$ and divided into five equal portions $(n=150$, in total) and then assigned randomly into five groups (stored at $-1,-6,-9,-12$, and $\left.-18^{\circ} \mathrm{C}\right)$. Beef samples were vacuum packaged and allocated to six freezers with temperatures monitored. Based on our previous study [13], considering the shelf-life of beef samples, the present experimental durations for samples stored at $-1,-6,-9,-12$, and $-18^{\circ} \mathrm{C}$ were set to $28,84,126,168$, and 168 days, respectively. The refrigeration conditions were stable, and each sample was held at the set temperature throughout whole storage.

2.2. Myofibrillar Protein Extraction. Frozen beef samples were thawed at $4^{\circ} \mathrm{C}$ overnight. Myofibrillar protein (MP) was extracted according to the method described by Li et al. [14]. Thawed beef samples $(10 \mathrm{~g})$ were homogenized for $30 \mathrm{~s}$ with $40 \mathrm{~mL}$ ice-cold $20 \mathrm{mM}$ phosphate buffer ( $\mathrm{pH} 7.0$ ) in a blender (7012G, Waring, USA). After centrifuging (2,000x $g$, $4^{\circ} \mathrm{C}, 15 \mathrm{~min}$ ) and discarding the supernatant, the myofibril pellet was washed twice with $40 \mathrm{~mL}$ phosphate buffer and centrifuged under the same conditions. After that, the myofibril pellet was washed two more times by $40 \mathrm{~mL} 0.1 \mathrm{M}$ $\mathrm{NaCl}$ and centrifuged using the same conditions. The purified MP isolate was collected and stored in a tightly capped bottle (in $4^{\circ} \mathrm{C}$ refrigerator) and utilized within $48 \mathrm{~h}$. Protein concentration of the purified MP isolate was measured by the biuret method using bovine serum albumin (Sigma Chemical Co., St. Louis, MO) as standard. For each treatment group, three MP samples from three steaks were used to conduct the following tests.

2.3. Sulfhydryl Content. The measurement of sulfhydryl content was performed as described by Li et al. [14]. An aliquot of the $1.0 \mathrm{~mL}$ MP sample $(2.0 \mathrm{mg} / \mathrm{mL})$ was added to $1.0 \mathrm{~mL}$ Tris- $\mathrm{HCl}$ buffer (6 M guanidine hydrochloride, $1 \mathrm{mM}$ EDTA, pH 8.3). After incubation $\left(25^{\circ} \mathrm{C}\right.$ for $\left.30 \mathrm{~min}\right)$ with

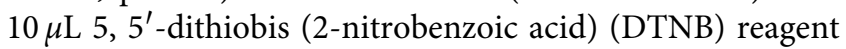

(10 mM DTNB in $100 \mathrm{mM}$ Tris-HCl buffer, $\mathrm{pH} 7.6$ ), the solution was measured at the absorbance of $412 \mathrm{~nm}$. Sample blanks without DTNB were prepared. The value of sulfhydryl content (nmol/mg protein) was calculated by using a molar absorption of $13,600 \mathrm{M}^{-1} \mathrm{~cm}^{-1}$.

2.4. Carbonyl Content. Carbonyl content of MP samples was determined as described by Park et al. [15]. An aliquot of $0.1 \mathrm{~mL}$ MP solution $(2.0 \mathrm{mg} / \mathrm{mL})$ was incubated with $0.5 \mathrm{~mL}$ $10 \mathrm{mM}$ 2,4-dinitrophenylhydrazine (DNPH) in $2.0 \mathrm{M} \mathrm{HCl}$ at $25^{\circ} \mathrm{C}$ for $40 \mathrm{~min}$. The control sample was incubated with $0.5 \mathrm{~mL} 2.0 \mathrm{M} \mathrm{HCl}$ at $25^{\circ} \mathrm{C}$ for $40 \mathrm{~min}$. After the incubation, $0.5 \mathrm{~mL}$ trichloroacetic acid $(20 \%)$ was added to the aliquot and centrifuged at $11,000 \times \mathrm{g}$ for $10 \mathrm{~min}$ at $4^{\circ} \mathrm{C}$. The precipitate was washed three times with $1.0 \mathrm{~mL}$ ethanol: ethyl acetate $(1: 1, \mathrm{~V} / \mathrm{V})$ mixture to remove unreacted DNPH. After that, the precipitate was blow-dried and incubated with $1.0 \mathrm{~mL}$ guanidine hydrochloride $(6.0 \mathrm{M})$ at $37^{\circ} \mathrm{C}$ for $30 \mathrm{~min}$. The solution was measured at the absorbance of $370 \mathrm{~nm}$. The value of carbonyl content ( $\mathrm{nmol} / \mathrm{mg}$ protein) was calculated by using a molar absorption of $22,000 \mathrm{M}^{-1} \mathrm{~cm}^{-1}$.

2.5. $\mathrm{Ca}^{2+}$-ATPase Activity. $\mathrm{Ca}^{2+}$-ATPase activity was measured according to the method of Pan et al. [16] with slight modifications. The blank was conducted by replacing the MP solution with $0.6 \mathrm{M} \mathrm{NaCl}$. The results were expressed as $\mu \mathrm{mol} / \mathrm{mg}$ protein $/ \mathrm{h}$.

2.6. Surface Hydrophobicity. Surface hydrophobicity of MP samples was measured as described by Chelh et al. [17]. $2.0 \mathrm{~mL}$ of MP solution $(2.0 \mathrm{mg} / \mathrm{mL})$ was reacted with $40 \mu \mathrm{L}$ $1.0 \mathrm{mg} / \mathrm{mL}$ bromophenol blue (BPB) $\left(\mathrm{pH} \mathrm{6.0)}\right.$ at $25{ }^{\circ} \mathrm{C}$ for $15 \mathrm{~min}$ and then centrifuged $\left(4,000 \times \mathrm{g}, 4^{\circ} \mathrm{C}\right)$ for $15 \mathrm{~min}$. The control was prepared by adding $40 \mu \mathrm{L} 1.0 \mathrm{mg} / \mathrm{mL} \mathrm{BPB}$ to $2.0 \mathrm{~mL} 20 \mathrm{mM}$ phosphate buffer ( $\mathrm{pH}$ 7.0). The solution was measured at the absorbance of $595 \mathrm{~nm}$ against a phosphate buffer blank. The amount of bound BPB, expressed as the difference between total and free $\mathrm{BPB}$, acts as an indicator of protein surface hydrophobicity. The value was calculated by using following equation: bound $\mathrm{BPB}(\mu \mathrm{g}) / \mathrm{mg}$ protein $=40 \mu \mathrm{g} *\left(\mathrm{OD}_{\text {control }}-\mathrm{OD}_{\text {sample }}\right) / \mathrm{OD}_{\text {control }}$.

2.7. Ionic Bonds and Hydrogen Bonds. Measurements of ionic bonds and hydrogen bonds were performed according to the method of Gómez-Guillén et al. [18]. $2.0 \mathrm{~mL} \mathrm{MP}$ samples $(2.0 \mathrm{mg} / \mathrm{mL})$ were mixed with $10 \mathrm{~mL}$ three solutions $(0.05 \mathrm{~mol} / \mathrm{L} \mathrm{NaCl}(\mathrm{SA}), 0.6 \mathrm{~mol} / \mathrm{L} \mathrm{NaCl}(\mathrm{SB})$, and $0.6 \mathrm{~mol} / \mathrm{L}$ $\mathrm{NaCl}+1.5 \mathrm{~mol} / \mathrm{L}$ urea (SC)), respectively. MP was partially solubilized with these solutions to detect the existences of ionic bonds (difference between the concentration of MP solubilized in SB and SA) and hydrogen bonds (difference between the concentration of MP solubilized in SC and SB). The mixture was allowed to stand for 1 hour at $4^{\circ} \mathrm{C}$ and then centrifuged $\left(12,000 \times \mathrm{g}, 4^{\circ} \mathrm{C}\right)$ for $15 \mathrm{~min}$. Protein concentration of the supernatant was measured by using the Biuret method. The results of ionic bonds and hydrogen bonds were expressed as soluble protein (g)/supernatant (L). 
2.8. Secondary Structure. Secondary structure of MP was determined by using Fourier transformation infrared spectrum (FTIR), and the measurement was conducted according to the method of Gangidi et al. [19]. A Fourier transform infrared spectrometer equipped with MB-ATR (multibounce attenuated total reflectance) was used to obtain the spectra of the MP samples which were collected at the end of each storage period, and the concentration was adjusted to $10 \mathrm{mg} / \mathrm{mL}$ by using $20 \mathrm{mM}$ phosphate buffer $(\mathrm{pH}$ 7.0). The spectra of MP samples were determined in the range of $4,000 \sim 400 \mathrm{~cm}^{-1}$ by OMNIC software. A total of 64 scans at a resolution of $4 \mathrm{~cm}^{-1}$ were collected. Deconvolution of the obtained infrared spectra was conducted using the PeakFit Analysis Program.

2.9. Differential Scanning Calorimetry (DSC). The thermal stability of beef muscle proteins was examined by a differential scanning calorimeter (Q200, TA, USA) according to the method of Bertram et al. [20] with slight modifications. At the end of each storage period, frozen beef samples were collected and thawed at $4^{\circ} \mathrm{C}$ overnight. The beef sample $(15 \mathrm{mg})$ was placed in a tightly sealed aluminium cell and accurately weighed whereas another empty aluminium cell was used as reference. The sealed aluminium cells were subjected to DSC analysis, where the heat of fusion was measured by rising the temperature from $20^{\circ} \mathrm{C}$ to $100^{\circ} \mathrm{C}$ at a rate of $5^{\circ} \mathrm{C} / \mathrm{min}$ and then cooled to $20^{\circ} \mathrm{C}$. The transition temperature $\left(T_{m},{ }^{\circ} \mathrm{C}\right)$ and enthalpy $(\Delta H, \mathrm{~J} / \mathrm{g})$ value were analysed by using the Universal Analysis 2000 software.

2.10. Quality Properties. The quality properties of beef samples including colour, shear force value, drip loss, and protein content of thawing drip were determined at the end of each storage period. For each treatment, six steaks were used to conduct the test $(n=6)$. Colour measurement was performed as described by Li et al. [14]. A chroma colorimeter (model no. CR-400, Konica Minolta Sensing Americas Inc., USA) was used to measure the $L^{*}, a^{*}$, and $b^{*}$ values. Shear force values were measured as described according to Qian et al. [13] by using the TA-XT2 texture analyser (Stable Micro Systems, UK) with a knife blade (code HDP/BS, Stable Micro Systems, UK). The crosshead speed of the knife blade was $2 \mathrm{~mm} / \mathrm{s}$ with the distance of $30 \mathrm{~mm}$. Six samples $(1 \times 1 \times 2 \mathrm{~cm})$ cut parallel to the muscle fibres were obtained from each treatment. The results were expressed in grams. Drip loss measurement was measured according to the method described by Lan et al. [21] with slight modifications. After the storage period, samples were thawed at $4^{\circ} \mathrm{C}$ and weighed after wiping drips from its surface. The percentage of drip loss was calculated according to the following equation: drip loss $(\%)=$ (weight of raw material - weight after thawing $) /$ (weight of raw material) $\times 100$. In addition, the protein content of thawing drip was determined by Kjeldahl analysis with an automatic Kjeldahl apparatus (Kjeltec 2300, FOSS, Denmark).
2.11. Statistical Analyses. All experiments were determined at least in triplicate, and the data were presented as means \pm standard deviations (SD). Data were analysed using the general linear model procedures of SPSS Statistics 16.0. Each triplicate was included as a random factor, and different frozen temperatures were arranged as fixed factors. Duncan's multiple range test was used to determine the significance (with significance defined as $P<0.05$ ).

\section{Results and Discussion}

3.1. Sulfhydryl Content. The sulfhydryl group acts as one of the most reactive functional groups in proteins. The changes in conformation of proteins could be reflected by the transition between sulfhydryl groups and disulfide linkage [11]. During storage, the changes observed in sulfhydryl content of MP are shown in Figure 1. Sulfhydryl content of the beef MP decreased with storage time for all groups, and similar phenomenon was reported for refrigerated beef meatballs by Turgut et al. [22]. At the end of each storage duration, the sulfhydryl content of MP samples subjected to $-1,-6,-9,-12$, and $-18^{\circ} \mathrm{C}$ remained $41.2,54.2,49.3,49.6$, and $53.9 \%$ of the initial values, respectively. Over the same storage period, significantly greater sulfhydryl content $(P<0.05)$ for samples stored at $-9,-12$, and $-18^{\circ} \mathrm{C}$ was observed compared with samples subjected to -1 and $-6^{\circ} \mathrm{C}$. Interestingly, the sulfhydryl content did not show significant difference $(P>0.05)$ among the MP samples subjected at -9 , -12 , and $-18^{\circ} \mathrm{C}$ throughout the storage period. During frozen storage, the ice crystal formation would lead to changes in spatial structure of MP which further induce thiol groups to expose at the intramolecular level [23]. The oxidation of thiol groups promotes the formation of disulfide bonds, and as a result, sulfhydryl content consistently decreases during frozen storage [24]. These results indicated that lower storage temperature could inhibit the oxidation of thiol groups to a certain extent.

3.2. Carbonyl Content. The changes observed in carbonyl content of MP during storage are shown in Figure 2. As can be seen, the carbonyl content of the beef MP increased with storage time for all groups. During frozen storage, oxidative damage leads to the irreversible conversion of specific amino acid side chains into carbonyl groups [25]. The protein oxidation positively correlates with the carbonyl content $[10,26]$. Samples subjected to $-9,-12$, and $-18^{\circ} \mathrm{C}$ had rather slower rises in carbonyl content than samples held at -1 and $-6^{\circ} \mathrm{C}$. The carbonyl contents of samples subjected to -1 and $-6^{\circ} \mathrm{C}$ reached around $20 \mathrm{nmol} / \mathrm{mg}$ protein at 28 and 84 days, respectively. However, regarding the $-9,-12$, and $-18^{\circ} \mathrm{C}$ treatment groups, the carbonyl contents remained below $18.7 \mathrm{nmol} / \mathrm{mg}$ protein throughout the storage period. Furthermore, over the same storage period, significantly lower $(P<0.05))$ carbonyl contents were observed for samples stored at -12 and $-18^{\circ} \mathrm{C}$ compared with -1 and $-6^{\circ} \mathrm{C}$. Throughout storage duration, the carbonyl content did not show significant difference $(P>0.05)$ between -12 and $-18^{\circ} \mathrm{C}$ treatment groups. In the current study, the decrease in 


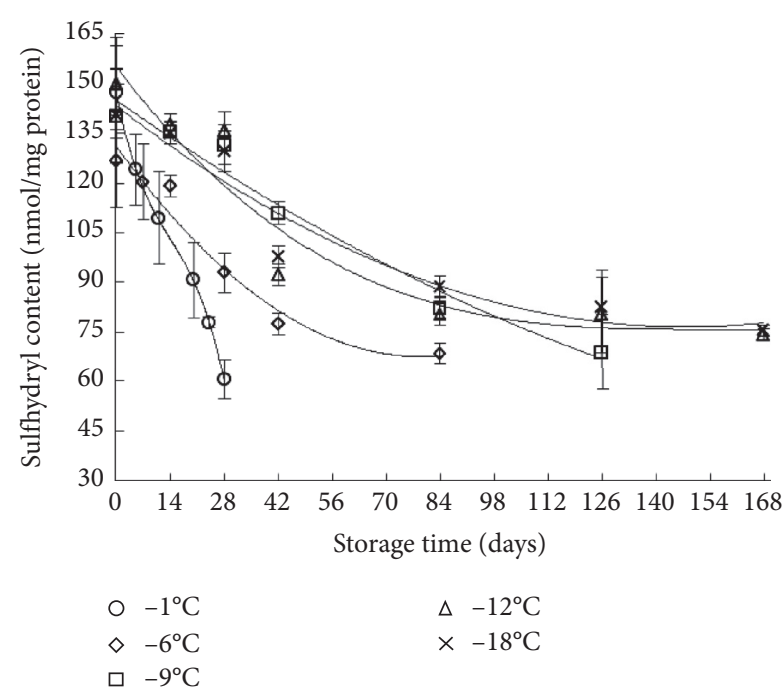

Figure 1: Changes in the sulfhydryl content of beef MP during storage at $-1,-6,-9,-12$, and $-18^{\circ} \mathrm{C}$.

sulfhydryl content of beef MP was found with a concomitant increase in carbonyl content, and a similar phenomenon was reported by Li et al., [14].

3.3. $\mathrm{Ca}^{2+}$-ATPase Activity. $\mathrm{Ca}^{2+}$-ATPase activity is widely used as an indicator of the integrity of myosin molecules. Godiksen et al. [27] believes that freeze-induced denaturation of MP would trigger the reduction of $\mathrm{Ca}^{2+}$-ATPase activity. As can be seen from Figure 3, the storage temperature and duration had significantly affected the $\mathrm{Ca}^{2+}$ ATPase activity of beef MP $(P<0.05)$. Regarding all the MP samples, the $\mathrm{Ca}^{2+}$-ATPase activity consistently decreased with storage time, and a similar phenomenon was reported by Wu et al. [24]. During frozen storage, the generated ice crystals would induce the aggregation of myosin globular head and conformational changes in MP, which leads to the rapid loss in $\mathrm{Ca}^{2+}$-ATPase activity in the early stage of the storage period [3]. Meanwhile, oxidation of total sulfhydryl and formation of disulfide bond could also reduce the $\mathrm{Ca}^{2+}$ ATPase activity [27]. In agreement, the current study found a decrease in $\mathrm{Ca}^{2+}$-ATPase activity with a concomitant increase in sulfhydryl content (Figure 1). $\mathrm{Ca}^{2+}$-ATPase activity of samples subjected to $-9,-12$, and $-18^{\circ} \mathrm{C}$ showed significantly slower decrease compared to the samples subjected to -1 and $-6^{\circ} \mathrm{C}$. Not surprisingly, over the same storage period, samples subjected to lower temperatures exhibited higher $\mathrm{Ca}^{2+}$-ATPase activity. Particularly, no significant differences $(P>0.05)$ were found between the $\mathrm{Ca}^{2+}$-ATPase activity between -12 and $-18^{\circ} \mathrm{C}$ treatment groups throughout the storage period.

3.4. Surface Hydrophobicity. Surface hydrophobicity, regarded as an indicator of subtle structural changes in proteins, is widely used to further assess the conformational stability of MP [28]. As can be seen from Figure 4, a sharp increase in protein surface hydrophobicity of samples stored at $-1^{\circ} \mathrm{C}$ was observed in the early stage of storage. The

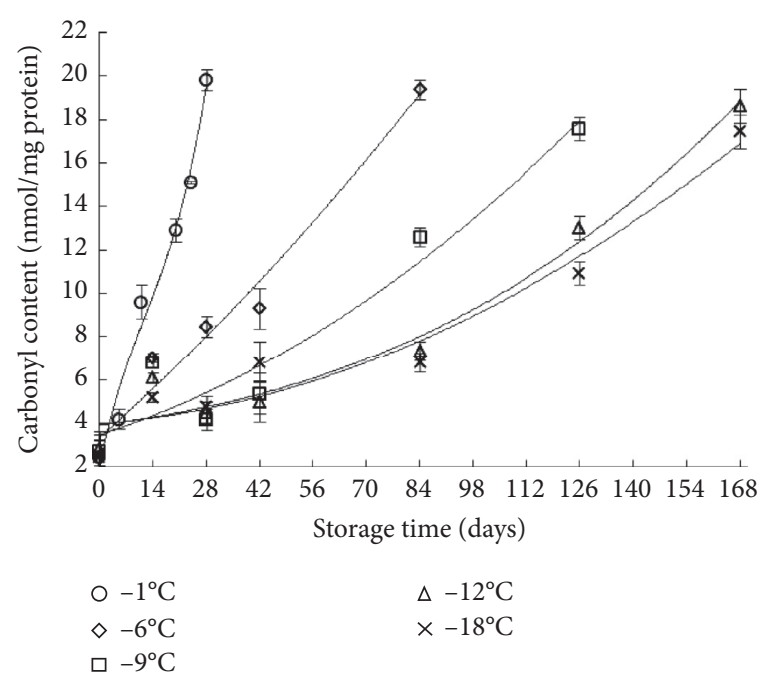

FIgURE 2: Changes in the carbonyl content of beef MP during storage at $-1,-6,-9,-12$, and $-18^{\circ} \mathrm{C}$.

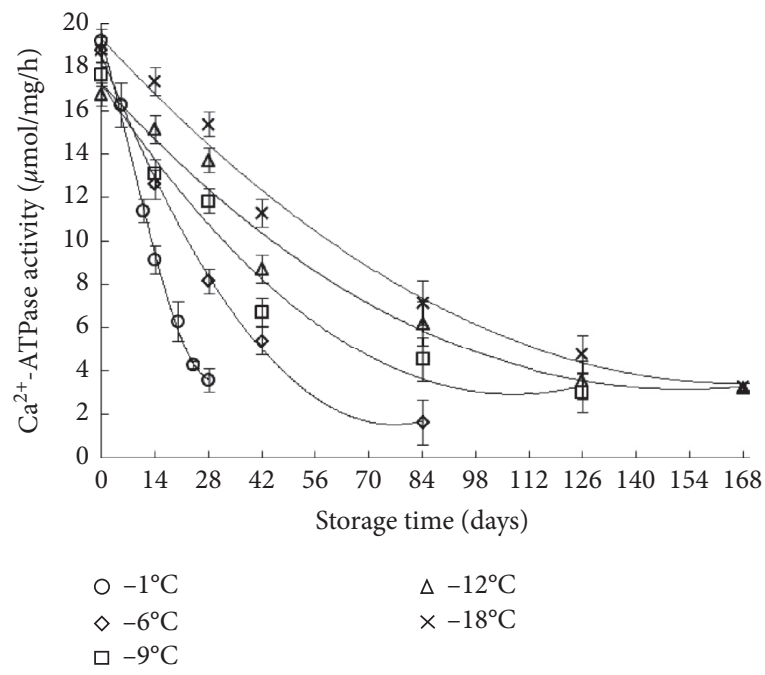

FIgURE 3: Changes in the $\mathrm{Ca}^{2+}$-ATPase activity of beef MP during storage at $-1,-6,-9,-12$, and $-18^{\circ} \mathrm{C}$.

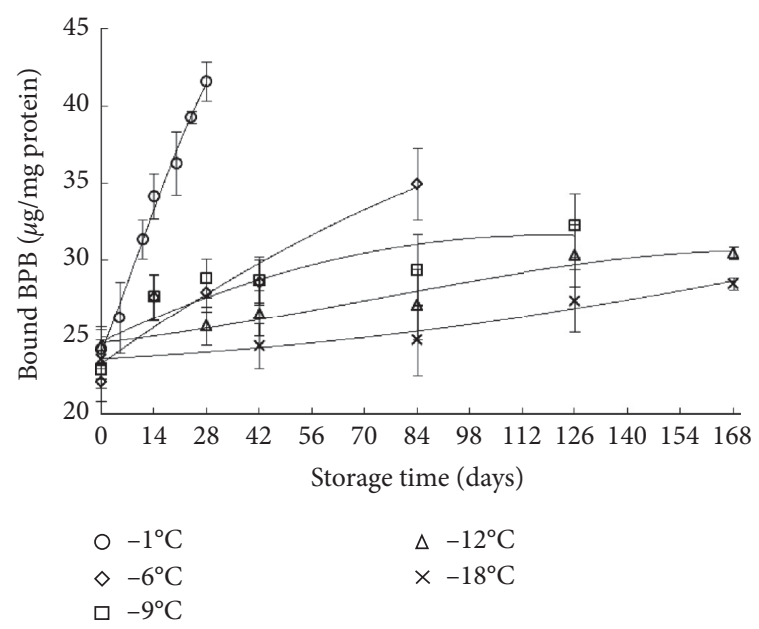

FIGURE 4: Changes in the surface hydrophobicity of beef MP during storage at $-1,-6,-9,-12$, and $-18^{\circ} \mathrm{C}$. 
samples subjected to $-6,-9,-12$, and $-18^{\circ} \mathrm{C}$ also showed consistently increasing trends. At the end of each storage period, the surface hydrophobicity increased by $71.9,58.4$, $40.6,24.6$, and $20.3 \%$ for samples held at $-1,-6,-9,-12$, and $-18^{\circ} \mathrm{C}$, respectively. During frozen storage, protein molecules are stretched and unfolded due to the formation of ice crystals, and as a result, the conformational structures of protein became loose and destabilized [29]. In the present study, the increase in surface hydrophobicity of the MP sample was found with a concomitant decrease in $\mathrm{Ca}^{2+}$ ATPase activity which revealed the conformational changes in MP. Consequently, the protein surface hydrophobicity increased with frozen storage duration. Over the same storage period, the surface hydrophobicity of samples subjected to $-9,-12$, and $-18^{\circ} \mathrm{C}$ was significantly lower $(P<0.05)$ than that of -1 and $-6^{\circ} \mathrm{C}$. These results indicated that lowering storage temperature could effectively maintain MP conformational stability.

3.5. Ionic Bonds and Hydrogen Bonds. Ionic bonds and hydrogen bonds play a key role in maintaining stability of protein structures, especially the interaction between proteins and water [30], which could reflect water-holding capacity of protein. The changes observed in ionic bonds and hydrogen bonds of MP during storage are shown in Figure 5. The ionic bonds and hydrogen bonds tended to decrease sharply with storage duration in all treatment groups. These results might be attributed to the alteration of the charged polar groups on the amino acid residues and the reduced net charge on the surface of proteins that occurred with freezeinduced denaturation [31]. These changes could lead to the reduced reactions between the polar groups and water molecules and further give rise to the fracture of ionic bonds and hydrogen bonds. MP samples subjected to $-9,-12$, and $-18^{\circ} \mathrm{C}$ showed rather slower decreases compared to that of -1 and $-6^{\circ} \mathrm{C}$. Among these groups $\left(-6,-9,-12\right.$, and $\left.-18^{\circ} \mathrm{C}\right)$, samples subjected to -12 and $-18^{\circ} \mathrm{C}$ showed relatively higher ionic bonds and hydrogen bonds, and no significant difference was observed between -12 and $-18^{\circ} \mathrm{C}$ treatment groups $(P>0.05)$.

3.6. Secondary Structure. The relative contents of $\alpha$-helix, $\beta$ sheet, $\beta$-turn, and random coilin beef MP are presented in Table 1. $\alpha$-helix and $\beta$-sheet are the representatives of ordered structure, whereas $\beta$-turn and random coil represent the disordered structure [32]. As can be seen from Table 1, at the end of each storage period, samples subjected to lower temperatures exhibited higher relative contents of $\alpha$-helix, and however, for the values of $\beta$-turn and random coil, they showed an opposite trend. During frozen storage, the freezing-induced protein denaturation would unfold the protein molecule chains and rupture partial hydrogen bonds. Consequently, the damage in the forces that stabilize the protein structure such as hydrogen bonds would trigger the reduction of ordered structure [33]. In the present study, samples subjected to lower temperatures showed greater hydrogen bonds (Figure 5), which is in agreement with the above findings.
3.7. Differential Scanning Calorimetry (DSC). The DSC thermograms of beef samples after frozen storage are shown in Figure 6. Thermograms of samples in all groups indicated three main transitions and, namely, Peak I (myosin), Peak II (sarcoplasmic proteins), and Peak III (actin) [20]. Table 2 presents the transition temperatures and enthalpy values of beef samples after frozen storage. As can be seen, for all transitions (Peak I, Peak II, and Peak III), higher transition temperature $\left(T_{m}\right)$ and enthalpy value $(\Delta H)$ were observed for beef samples subjected to lower storage temperature, and similar phenomenon was reported for mackerel by Saeed \& Howell [12]. Particularly, no significant differences $(P>0.05)$ were found in $T_{m}$ and $\Delta H$ of beef samples subjected to -12 and $-18^{\circ} \mathrm{C}$ after 168 days of storage. The enthalpy value $(\Delta H)$ is closely related to the content of ordered secondary structure of proteins [34]. In the present study, the increase in $\Delta H$ was founded with a concomitant increase in relative contents of $\alpha$-helix in MP, which is corresponded to the above study. The values of $T_{m}$ and $\Delta H$ could reflect the extent of protein denaturation [35]. The DSC results indicated that lower storage temperatures could more effectively suppress the protein denaturation. Additionally, storage at $-12^{\circ} \mathrm{C}$ got similar inhibitory effects on beef protein denaturation compared with $-18^{\circ} \mathrm{C}$ after 168 days of storage, which is in agreement with the above findings.

3.8. Quality Properties. The quality properties of beef samples after frozen storage including colour, shear force value, and drip loss are shown in Table 3. The surface colour of the beef samples after storage was measured by lightness $\left(L^{*}\right)$, redness $\left(a^{*}\right)$, and yellowness $\left(b^{*}\right)$. Beef samples subjected to -12 and $-18^{\circ} \mathrm{C}$ exhibited relatively higher $a^{*}$ value and lower $b^{*}$ value than other groups. Holman et al. [36] noted that $a^{*}$ values (redness) provided the best prediction of consumer acceptance of beef colour and which was considered acceptable when $a^{*}$ values were equal to or above 14.5. Compared to $-1,-6$, and $-9^{\circ} \mathrm{C}$, storage at -12 and $-18^{\circ} \mathrm{C}$ could provide a better protective effect against beef discolouration. The shear force value of samples stored at -12 and $-18^{\circ} \mathrm{C}$ was significantly higher $(P<0.05)$ than that of $-1,-6$, and $-9^{\circ} \mathrm{C}$, which could be ascribed to the longer storage duration. After frozen storage, the beef samples stored at -12 and $-18^{\circ} \mathrm{C}$ exhibited significantly lower $(P<0.05)$ drip loss than that in samples stored at -1 and $-6^{\circ} \mathrm{C}$. In addition, the protein content of drip from samples subjected to $-12^{\circ} \mathrm{C}(9.41 \%)$ and $-18^{\circ} \mathrm{C}(9.21 \%)$ was also significantly lower $(P<0.05)$ than that of $-1^{\circ} \mathrm{C}(10.29 \%)$ and $-6^{\circ} \mathrm{C}(9.78 \%)$. The drip contains substances and water that leaked from disrupted cells caused by freeze treatment. This damage effects induced by ice crystal formation can be alleviated by lowering frozen temperature [37]. Particularly, no significant differences $(P>0.05)$ were found in the quality properties among the beef samples subjected to $-12^{\circ} \mathrm{C}$ and $-18^{\circ} \mathrm{C}$, which was corresponded with the aforementioned results of myofibrillar protein denaturation. 


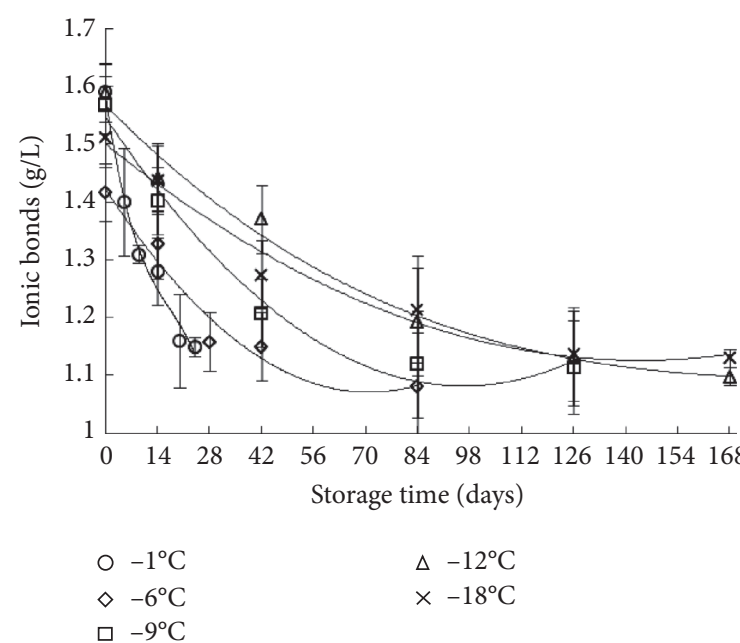

(a)

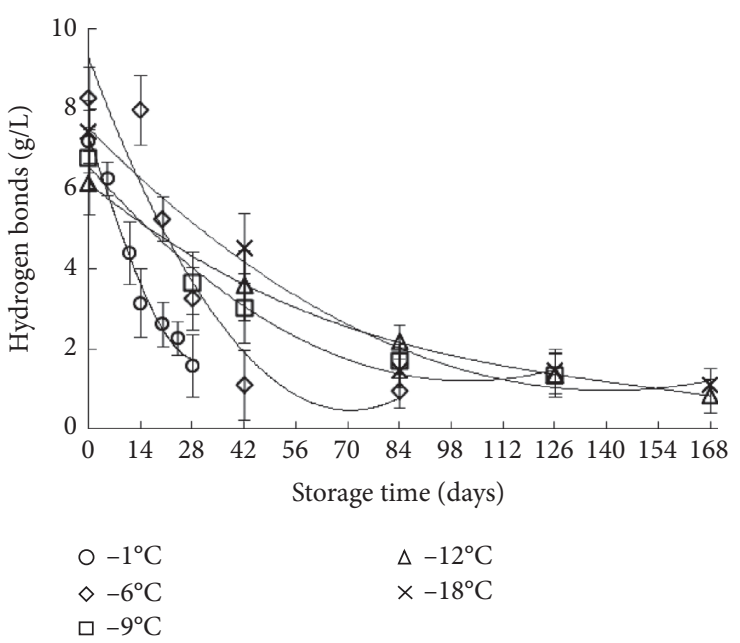

(b)

Figure 5: Changes in the ionic bonds (a) and hydrogen bonds (b) of beef MP during storage at $-1,-6,-9,-12$, and $-18^{\circ} \mathrm{C}$.

TABLE 1: Secondary structure relative contents of beef MP after frozen at $-1^{\circ} \mathrm{C}$ (for 28 days), $-6^{\circ} \mathrm{C}$ (for 84 days), $-9^{\circ} \mathrm{C}$ (for 126 days), $-12^{\circ} \mathrm{C}$ (for 168 days), and $-18^{\circ} \mathrm{C}$ (for 168days).

\begin{tabular}{lcccc}
\hline Storage temperature & $\alpha$-Helix $(\%)$ & $\beta$-Sheet(\%) & $\beta$-Turn(\%) & Random coil(\%) \\
\hline$-1^{\circ} \mathrm{C}$ & $15.3 \pm 0.9^{\mathrm{c}}$ & $41.6 \pm 1.2^{\mathrm{a}}$ & $25.5 \pm 1.3^{\mathrm{a}}$ & $17.6 \pm 1.0^{\mathrm{c}}$ \\
$-6^{\circ} \mathrm{C}$ & $18.4 \pm 1.2^{\mathrm{b}}$ & $40.6 \pm 1.4^{\mathrm{ab}}$ & $22.2 \pm 0.7^{\mathrm{b}}$ & $18.8 \pm 0.9^{\mathrm{b}}$ \\
$-9^{\circ} \mathrm{C}$ & $20.0 \pm 0.5^{\mathrm{ab}}$ & $40.6 \pm 1.4^{\mathrm{ab}}$ & $20.9 \pm 1.6^{\mathrm{c}}$ & $18.5 \pm 0.4^{\mathrm{b}}$ \\
$-12^{\circ} \mathrm{C}$ & $20.9 \pm 0.94^{\mathrm{ab}}$ & $38.3 \pm 1.76^{\mathrm{b}}$ & $21.3 \pm 0.95^{\mathrm{bc}}$ & $19.5 \pm 0.73^{\mathrm{b}}$ \\
$-18^{\circ} \mathrm{C}$ & $22.4 \pm 1.01^{\mathrm{a}}$ & $38.0 \pm 1.95^{\mathrm{b}}$ & $22.7 \pm 0.71^{\mathrm{b}}$ & $16.9 \pm 0.63^{\mathrm{c}}$ \\
\hline
\end{tabular}

Values represent means $\pm \mathrm{SD}(n=3)$. Different lowercase letters in the same column indicate significant differences $(P<0.05)$.

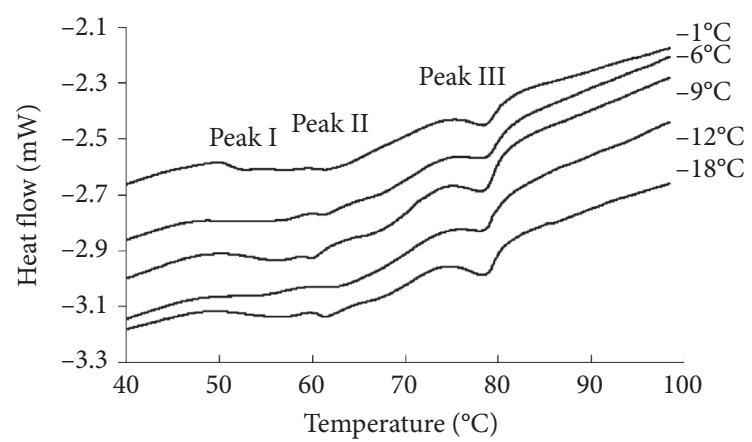

Figure 6: DSC thermograms of beef after frozen at $-1^{\circ} \mathrm{C}$ (for 28 days), $-6^{\circ} \mathrm{C}$ (for 84 days), $-9^{\circ} \mathrm{C}$ (for 126 days), $-12^{\circ} \mathrm{C}$ (for 168 days), and $-18^{\circ} \mathrm{C}$ (for 168 days).

TABLE 2: Transition temperature $\left(T_{m},{ }^{\circ} \mathrm{C}\right)$ and enthalpy $(\Delta H, \mathrm{~J} / \mathrm{g})$ value of beef after frozen at $-1^{\circ} \mathrm{C}$ (for 28 days), $-6^{\circ} \mathrm{C}$ (for 84 days), $-9^{\circ} \mathrm{C}($ for 126 days), $-12^{\circ} \mathrm{C}$ (for 168 days), and $-18^{\circ} \mathrm{C}$ (for 168 days).

\begin{tabular}{|c|c|c|c|c|c|c|}
\hline \multirow{2}{*}{ Storage temperature } & \multicolumn{2}{|c|}{ Peak I } & \multicolumn{2}{|c|}{ Peak II } & \multicolumn{2}{|c|}{ Peak III } \\
\hline & $T_{m}\left({ }^{\circ} \mathrm{C}\right)$ & $\Delta H(\mathrm{~J} / \mathrm{g})$ & $T_{m}\left({ }^{\circ} \mathrm{C}\right)$ & $\Delta H(\mathrm{~J} / \mathrm{g})$ & $T_{m}\left({ }^{\circ} \mathrm{C}\right)$ & $\Delta H(\mathrm{~J} / \mathrm{g})$ \\
\hline$-1^{\circ} \mathrm{C}$ & $56.0 \pm 1.3^{\mathrm{b}}$ & $0.06 \pm 0.00^{c}$ & $59.9 \pm 0.8^{\mathrm{c}}$ & $0.05 \pm 0.004^{\mathrm{b}}$ & $77.5 \pm 0.2^{\mathrm{b}}$ & $0.34 \pm 0.06^{\mathrm{ab}}$ \\
\hline$-6^{\circ} \mathrm{C}$ & $56.4 \pm 0.8^{\mathrm{a}}$ & $0.08 \pm 0.00^{\mathrm{b}}$ & $60.4 \pm 0.1^{\mathrm{b}}$ & $0.07 \pm 0.004^{\mathrm{ab}}$ & $77.5 \pm 0.3^{\mathrm{b}}$ & $0.35 \pm 0.06^{\mathrm{a}}$ \\
\hline$-9^{\circ} \mathrm{C}$ & $56.6 \pm 0.2^{\mathrm{a}}$ & $0.10 \pm 0.01^{\mathrm{a}}$ & $60.7 \pm 0.4^{\mathrm{ab}}$ & $0.08 \pm 0.003^{\mathrm{a}}$ & $77.9 \pm 0.4^{\mathrm{ab}}$ & $0.37 \pm 0.05^{\mathrm{a}}$ \\
\hline$-12^{\circ} \mathrm{C}$ & $56.5 \pm 0.2^{\mathrm{a}}$ & $0.13 \pm 0.00^{\mathrm{a}}$ & $61.3 \pm 0.8^{\mathrm{a}}$ & $0.10 \pm 0.009^{\mathrm{a}}$ & $78.0 \pm 0.3^{\mathrm{a}}$ & $0.36 \pm 0.02^{\mathrm{a}}$ \\
\hline$-18^{\circ} \mathrm{C}$ & $56.7 \pm 0.1^{\mathrm{a}}$ & $0.15 \pm 0.02^{\mathrm{a}}$ & $61.4 \pm 0.6^{\mathrm{a}}$ & $0.12 \pm 0.002^{\mathrm{a}}$ & $78.1 \pm 0.3^{\mathrm{a}}$ & $0.38 \pm 0.04^{\mathrm{a}}$ \\
\hline
\end{tabular}

Values represent means \pm SD $(n=3)$. Different lowercase letters in the same column indicate significant differences $(P<0.05)$. 
TABle 3: Quality properties of beef after frozen at $-1^{\circ} \mathrm{C}$ (for 28 days), $-6^{\circ} \mathrm{C}$ (for 84 days), $-9^{\circ} \mathrm{C}$ (for 126 days), $-12^{\circ} \mathrm{C}$ (for 168 days), and $-18^{\circ} \mathrm{C}$ (for 168 days).

\begin{tabular}{lcccccc}
\hline Storage temperature & $L^{*}$ & $a^{*}$ & $b^{*}$ & Shear force $(\mathrm{g})$ & Drip loss (\%) & Protein content in drip (\%) \\
\hline$-1^{\circ} \mathrm{C}$ & $34.62 \pm 0.75^{\mathrm{a}}$ & $19.71 \pm 0.71^{\mathrm{c}}$ & $12.89 \pm 0.54^{\mathrm{a}}$ & $770.78 \pm 15.02^{\mathrm{d}}$ & $5.38 \pm 0.76^{\mathrm{a}}$ & $10.29 \pm 0.15^{\mathrm{a}}$ \\
$-6^{\circ} \mathrm{C}$ & $33.80 \pm 0.60^{\mathrm{b}}$ & $20.54 \pm 0.45^{\mathrm{b}}$ & $12.30 \pm 0.95^{\mathrm{a}}$ & $1041.00 \pm 9.49^{\mathrm{c}}$ & $4.29 \pm 0.38^{\mathrm{b}}$ & $9.78 \pm 0.10^{\mathrm{b}}$ \\
$-9^{\circ} \mathrm{C}$ & $33.56 \pm 1.03^{\mathrm{b}}$ & $20.39 \pm 1.16^{\mathrm{b}}$ & $10.20 \pm 0.75^{\mathrm{b}}$ & $1147.4 \pm 12.93^{\mathrm{b}}$ & $3.75 \pm 0.55^{\mathrm{c}}$ & $9.69 \pm 0.21^{\mathrm{bc}}$ \\
$-12^{\circ} \mathrm{C}$ & $32.97 \pm 0.71^{\mathrm{b}}$ & $21.33 \pm 0.71^{\mathrm{a}}$ & $9.37 \pm 1.21^{\mathrm{c}}$ & $1214.95 \pm 16.02^{\mathrm{a}}$ & $3.54 \pm 0.08^{\mathrm{cd}}$ & $9.41 \pm 0.19^{\mathrm{c}}$ \\
$-18^{\circ} \mathrm{C}$ & $33.67 \pm 0.99^{\mathrm{b}}$ & $21.04 \pm 0.46^{\mathrm{a}}$ & $8.18 \pm 0.54^{\mathrm{d}}$ & $1208.95 \pm 15.02^{\mathrm{a}}$ & $3.31 \pm 0.88^{\mathrm{d}}$ & $9.21 \pm 0.45^{\mathrm{c}}$ \\
\hline
\end{tabular}

Values represent means $\pm \mathrm{SD}(n=3)$. Different lowercase letters in the same column indicate significant differences $(P<0.05)$.

\section{Conclusion}

During frozen storage, the denaturation of myofibrillar protein in beef occurs gradually. Generally, for beef samples, a longer storage duration and higher storage temperature resulted in lower sulfhydryl content, $\mathrm{Ca}^{2+}$-ATPase activity, ionic bonds, hydrogen bonds, and higher surface hydrophobicity of myofibrillar protein. It can be concluded that the freeze-induced protein denaturation tends to less severe when the freezing temperature is lower. However, our study clearly showed that difference in frozen storage temperature $\left(-12\right.$ and $\left.-18^{\circ} \mathrm{C}\right)$ did not yield tangible effects upon the protein properties throughout the storage period (168 days) $(P>0.05)$. In this regard, lowering the freezing temperature may not minimize myofibrillar protein denaturation in a limited storage duration, which was also confirmed by the quality properties of beef samples after frozen storage. Given the close connection between myofibrillar protein and meat quality, these results could be beneficial to the meat-processing industry, especially when choosing suitable temperature for beef preservation. In terms of the protein denaturation, $-9^{\circ} \mathrm{C}$ might be more appropriate for beef which is consumed quickly. For the beef which demands long-term storage, $-12^{\circ} \mathrm{C}$ is more suitable for preservation compared to $-18^{\circ} \mathrm{C}$ (energy saving).

\section{Data Availability}

The data used to support the findings of this study are available from the corresponding author upon request.

\section{Additional Points}

Practical Application. Storage temperature is one of the most important factors for meat and meat product preservation. Present work could be beneficial to the meat-processing industry, especially when choosing suitable temperature for meat preservation, to extend the shelf-life of meat while avoiding temperature abuse.

\section{Conflicts of Interest}

The authors state that they have no conflicts of interest.

\section{Acknowledgments}

The authors would like to thank the National Natural Science Foundation of China (grant no. 31671789).

\section{References}

[1] S. M. E. Rahman, J. Park, K. B. Song et al., "Effects of slightly acidic low concentration electrolyzed water on microbiological, physicochemical, and sensory quality of fresh chicken breast meat," Journal of Food Science, vol. 77, no. 1, pp. 35-41, 2012.

[2] X. Lu, Y. Zhang, L. Zhu et al., "Effect of superchilled storage on shelf life and quality characteristics of M. longissimus lumborum from Chinese Yellow cattle," Meat Science, vol. 149, pp. 79-84, 2018.

[3] L. Shi, G. Xiong, A. Ding et al., "Effects of freezing temperature and frozen storage on the biochemical and physical properties of Procambarus clarkii," International Journal of Refrigeration, vol. 91, pp. 223-229, 2018.

[4] Y. Yeh, S. T. Omaye, F. A. Ribeiro, C. R. Calkins, and A. S. de Mello, "Evaluation of palatability and muscle composition of novel value-added beef cuts," Meat Science, vol. 135, pp. 79-83, 2018.

[5] D. L. Hopkins, D. F. Stanley, E. S. Toohey, G. E. Gardner, D. W. Pethick, and R. van de Ven, "Sire and growth path effects on sheep meat production. 2. Meat and eating quality," Australian Journal of Experimental Agriculture, vol. 47, no. 10, p. 1219, 2007.

[6] F. Li, B. Wang, Q. Liu et al., "Changes in myofibrillar protein gel quality of porcine longissimus muscle induced by its stuctural modification under different thawing methods," Meat Science, vol. 147, pp. 108-115, 2019.

[7] L. Jiang and S. Wu, "Pullulan suppresses the denaturation of myofibrillar protein of grass carp (Ctenopharyngodon idella) during frozen storage," International Journal of Biological Macromolecules, vol. 112, pp. 1171-1174, 2018.

[8] Z. Wu, H. C. Bertram, U. Böcker, R. Ofstad, and A. Kohler, "Myowater dynamics and protein secondary structural changes as affected by heating rate in three pork qualities: a combined FT-IR microspectroscopic and $1 \mathrm{H}$ nmr relaxometry study," Journal of Agricultural and Food Chemistry, vol. 55, no. 10, pp. 3990-3997, 2007.

[9] J. T. Y. Chan, D. A. Omana, and M. Betti, "Effect of ultimate $\mathrm{pH}$ and freezing on the biochemical properties of proteins in Turkey breast meat," Food Chemistry, vol. 127, no. 1, pp. 109-117, 2011.

[10] A. Soyer, B. Özalp, Ü. Dalmış, and V. Bilgin, "Effects of freezing temperature and duration of frozen storage on lipid and protein oxidation in chicken meat," Food Chemistry, vol. 120, no. 4, pp. 1025-1030, 2010.

[11] F. C. Ekezie, J. H. Cheng, and D. W. Sun, "Effects of atmospheric pressure plasma jet on the conformation and physicochemical properties of myofibrillar protein from king prawn (Litopenaeus vannamei)," Food Chemistry, vol. 276, no. 15, pp. 147-156, 2018. 
[12] S. Saeed and N. K. Howell, "Effect of lipid oxidation and frozen storage on muscle proteins of atlantic mackerel (scomberscombrus)," Journal of the Science of Food \& Agriculture, vol. 82, no. 5, pp. 579-586, 2010.

[13] S. Qian, X. Li, H. Wang et al., "Effect of sub-freezing storage $\left(-6,-9\right.$ and $\left.-12^{\circ} \mathrm{C}\right)$ on quality and shelf life of beef," International Journal of Food Science \& Technology, vol. 53, no. 9, pp. 2129-2140, 2018.

[14] Y. Li, X. Li, J.-z. Wang et al., "Effects of oxidation on water distribution and physicochemical properties of porcine myofibrillar protein gel," Food Biophysics, vol. 9, no. 2, pp. 169-178, 2014.

[15] D. Park, Y. L. Xiong, and A. L. Alderton, "Concentration effects of hydroxyl radical oxidizing systems on biochemical properties of porcine muscle myofibrillar protein," Food Chemistry, vol. 101, no. 3, pp. 1239-1246, 2007.

[16] J. Pan, H. Shen, J. You, and Y. Luo, "Changes in physiochemical properties of myofibrillar protein from silver carp (Hypophthalmichthys mollitrix) during heat treatment," Journal of Food Biochemistry, vol. 35, no. 3, pp. 939-952, 2011.

[17] I. Chelh, P. Gatellier, and V. Santé-Lhoutellier, “Technical note: a simplified procedure for myofibril hydrophobicity determination," Meat Science, vol. 74, no. 4, pp. 681-683, 2006.

[18] M. C. Gómez-Guillén, A. J. Borderías, and P. Montero, "Chemical interactions of nonmuscle proteins in the network of sardine (sardina pilchardus) muscle gels," LWT-Food Science and Technology, vol. 30, no. 6, pp. 602-608, 1997.

[19] R. R. Gangidi, A. Proctor, and F. W. Pohlman, "Rapid determination of spinal cord content in ground beef by attenuated total reflectance fourier transform infrared spectroscopy," Journal of Food Science, vol. 68, no. 1, pp. 124-127, 2003.

[20] H. C. Bertram, Z. Wu, F. van den Berg, and H. J. Andersen, "NMR relaxometry and differential scanning calorimetry during meat cooking," Meat Science, vol. 74, no. 4, pp. 684-689, 2006.

[21] Y. Lan, Y. Shang, Y. Song, and Q. Dong, "Changes in the quality of superchilled rabbit meat stored at different temperatures," Meat Science, vol. 117, pp. 173-181, 2016.

[22] S. S. Turgut, F. Işıkçı, and A. Soyer, "Antioxidant activity of pomegranate peel extract on lipid and protein oxidation in beef meatballs during frozen storage," Meat Science, vol. 129, pp. 111-119, 2017.

[23] W. Sompongse, Y. Itoh, and A. Obatake, "Effect of cryoprotectants and a reducing reagent on the stability of actomyosin during ice storage," Fisheries Science, vol. 62, no. 1, pp. 73-79, 1996.

[24] S. Wu, S. Pan, and H. Wang, "Effect of trehalose on lateolabrax japonicus myofibrillar protein during frozen storage," Food Chemistry, vol. 160, pp. 281-285, 2014.

[25] D. Park, Y. L. Xiong, A. L. Alderton, and T. Ooizumi, "Biochemical changes in myofibrillar protein isolates exposed to three oxidizing systems," Journal of Agricultural and Food Chemistry, vol. 54, no. 12, pp. 4445-4451, 2006.

[26] H. M. Badr and K. A. Mahmoud, "Antioxidant activity of carrot juice in gamma irradiated beef sausage during refrigerated and frozen storage," Food Chemistry, vol. 127, no. 3, pp. 1119-1130, 2011.

[27] H. Godiksen, G. Hyldig, and R. Jessen, "Sarcoplasmic reticulum Ca2+-ATPase and cytochrome oxidase as indicators of frozen storage in cod (Gadus morhua)," Journal of Food Science, vol. 68, no. 8, pp. 2579-2585, 2003.
[28] A. Zhou, S. Benjakul, K. Pan et al., "Cryoprotective effects of trehalose and sodium lactate on tilapia (Sarotherodonnilotica) surimi during frozen storage," Food Chemistry, vol. 96, no. 1, pp. 96-103, 2005.

[29] S. Ishizaki, M. Tanaka, R. Takai, and T. Taguchi, "Stability of fish myosins and their fragments to high hydrostatic pressure," Fisheries Science, vol. 61, no. 6, pp. 989-992, 1995.

[30] R. Adhikary, J. Zimmermann, J. Liu et al., "Evidence of an unusual N-H... N hydrogen bond in proteins," Journal of the American Chemical Society, vol. 136, no. 39, pp. 13474-13477, 2014.

[31] W. Visessanguan, S. Benjakul, S. Riebroy, and P. Thepkasikul, "Changes in composition and functional properties of proteins and their contributions to Nham characteristics," Meat Science, vol. 66, no. 3, pp. 579-588, 2004.

[32] M. Zhang, F. Li, X. Diao, B. Kong, and X. Xia, "Moisture migration, microstructure damage and protein structure changes in porcine longissimus muscle as influenced by multiple freeze-thaw cycles," Meat Science, vol. 133, pp. 10-18, 2017.

[33] H. Yang, W. Zhang, T. Li et al., "Effect of protein structure on water and fat distribution during meat gelling," Food Chemistry, vol. 204, pp. 239-245, 2016.

[34] I. Koshiyama, M. Hamano, and D. Fukushima, "A heat denaturation study of the $11 \mathrm{~S}$ globulin in soybean seeds," Food Chemistry, vol. 6, no. 4, pp. 309-322, 1981.

[35] S. Saeed and N. K. Howell, "Rheological and differential scanning calorimetry studies on structural and textural changes in frozen Atlantic mackerel(Scomber scombrus)," Journal of the Science of Food and Agriculture, vol. 84, no. 10, pp. 1216-1222, 2004.

[36] B. W. B. Holman, R. J. van de Ven Van, Y. Mao, C. E. O. Coombs, and D. L. Hopkins, "Using instrumental (CIE and reflectance) measures to predict consumers' acceptance of beef colour," Meat Science, vol. 127, pp. 57-62, 2017.

[37] F. Yang, D. Jing, D. Yu et al., "Differential roles of ice crystal, endogenous proteolytic activities and oxidation in softening of obscure pufferfish (Takifugu Obscurus) fillets during frozen storage," Food Chemistry, vol. 278, pp. 452-459, 2018. 